\title{
Peningkatan Pendapatan Petani Melalui Integrasi Kakao-Ternak Kambing di Desa Tapango Barat Kecamatan Tapango Kabupaten Polewali Mandar Provinsi Sulawesi Barat
}

\author{
Harli A. Karim ${ }^{\text {, }}$, Haeruddin² \\ 1,2Universitas Al - Asyariah Mandar \\ E-mail: ${ }^{1}$ Harli_karim@yahoo.com
}

INFO ARTIKEL

Available online

URL:

https://journal.stkipnurulhuda.ac.id/ index.php/JIMi/article/view/448

\section{How to cite (APA):}

Karim, H., \& Haeruddin, H. (2019). Peningkatan Pendapatan Petani Melalui Integrasi Kakao-Ternak Kambing di Desa Tapango Barat Kecamatan Tapango Kabupaten Polewali Mandar Provinsi Sulawesi Barat. Jurnal Indonesia Mengabdi, 1(1), 21-26.

This work is licensed under a Creative Commons Attribution 4.0 International License

\begin{abstract}
Abstrak
Upaya peningkatan pendapat masyarakat Desa Tapango Barat khususnya masyarakat mitra perlu mendapat perhatian. Peningkatan kemampuan petani mengelola lahannya bisa menjadi salah satu cara meningkatkan taraf hidup mitra. Kegiatan integrasi kakao-ternak kambing dapat meningkatkan mendapatan petani. Kebutuhan pupuk tanaman bisa didapatkan dari hasil kotoran ternak sehingga petani tidak perlu mengeluarkan biaya untuk membeli pupuk kimia, selain mahal, juga kurang ramah lingkungan. Selain itu, ternak kambing mendapatkan pakan dari hasil pangkasan daun kakao dan pohon pelindung yang juga terdapat pada pertanaman kakao. Petani mitra pada gilirannya, memperoleh keuntungan dari kakao maupun kambing dan dari penghematan biaya pemupukan. Pelaksanan kegiatan dengan menempatkan kandang ternak kambing di sela tanaman kakao sehingga luaran yang dihasilkan dapat mengatasi permasalahan tentang pakan ternak yang jauh dari lokasi kandang. Solusi lain yaitu melakukan penanaman pohon pelindung kakao yang dipersiapkan untuk pakan ternak kambing. Berbagai pelatihan telah dilakukan pada mitra antara lain : Pelatihan Peternakan Kambing, Pelatihan Teknik Pemeliharaan pada tanaman kakao, Pelatihan dan praktek pembuatan kompos berbahan dasar kotoran kambing dan limbah kakao.

Kata Kunci: Integrasi Kakao-Ternak Kambing, Pendapatan Petani.
\end{abstract}

\begin{abstract}
Efforts to increase the opinion of the people of Tapango Barat Village, especially partner communities, need attention. Increasing the ability of farmers to manage their land can be one way to improve the lives of partners. Integrated cocoa-goat livestock activities can increase farmers' income. Plant fertilizer needs can be obtained from the results of manure so that farmers do not need to pay for buying chemical fertilizers, besides being expensive, they are also less environmentally friendly. In addition, goats get feed from the results of cocoa leaf trimming and protective trees which are also found in cocoa plantations. Partner farmers, in turn, benefit from cocoa and goats and from saving on fertilizer costs. Implementation of activities by placing goat cages between cocoa plants so that the resulting output can overcome problems regarding fodder far from the location of the cage. Another solution is to plant a cocoa tree that is prepared for goat's feed. Various trainings have been conducted on partners including: Goat Husbandry Training, Maintenance Engineering Training on cocoa plants, Training and practice of composting made from goat manure and cocoa waste.
\end{abstract}

Keywords: Integration of Goat Cacao, Farmer Income. 


\section{PENDAHULUAN \\ Analisis Situasi}

Desa Tapango Barat secara geografis terletak Kecamatan Tapango Kabupaten Polewali Mandar. Jarak tempuh dari desa ke pusat kota Polewali Mandar kurang lebih $12 \mathrm{Km}$. Menurut Biro Pusat Statistik Kabupaten Polewali Mandar (2015) jumlah penduduk Desa Tapango Barat 970 KK dengan 1980 jiwa. $90 \%$ diantaranya menggantungkan hidup dari hasil pertanian di desa tersebut. Keadaan wilayah yang berada di dataran sedang (10-200 mdpl) dan akses jalan yang sulit sehingga Desa Tapango Barat tergolong desa tertinggal.

Berdasarkan data statistik (2015) pertanaman kakao sangat mendominasi di Tapango Barat. Luas tanaman kakao terdiri dari 3.090 ha dan melibatkan 980 petani. Artinya, tanaman kakao menjadi tumpuan hidup di desa tersebut. Meski kondisi iklim dan tanah Desa Tapango Barat sangat sesuai dengan tanaman kakao. Namun, produktivitas tanaman kakao di Kecamatan Tapango termasuk Desa Tapango Barat masih tergolong rendah. Produktivitas tanaman kakao kurang lebih $765 \mathrm{~kg} / \mathrm{ha} / \mathrm{tahun}$. Masih sangat rendah jika dibandingkan dengan potensi tanaman kakao yang bisa mencapai 1.500$2.000 \mathrm{~kg} / \mathrm{ha} /$ tahun (Asrul, Laode, 2014) Kondisi tersebut menjadikan tingkat pendapat masyarakat Desa Tapango Barat menjadi sangat rendah.

Potensi dan peluang usaha kakao mitra masih berpeluang untuk dikembangkan. Kakao masih menjadi komoditi unggulan dan menjadi perioritas di Desa Tapango Barat. Kakao merupakan salah satu komoditas andalan perkebunan yang peranannya cukup penting bagi perekonomian Desa Tapango Barat, khususnya sebagai penyedia lapangan kerja dan sumber pendapatan masyarakat.

Selain sebagai petani kakao masyarakat Desa Tapango Barat termasuk ketiga mitra umumnya memiliki ternak, seperti sapi, ayam dan kambing. Namun, masih skala kecil dan dikelola secara tradisional. Ternak dijadikan sebagai kegiatan sampingan tanpa ada sentuhan teknologi.

\section{Permasalahan Mitra}

Pertanaman kakao di Desa Tapango Barat masih menghadapi berbagai masalah yang kompleks antara lain produktivitas lahan masih rendah. Rata-rata produktivitas tanaman kakao milik mitra 650 $\mathrm{kg} / \mathrm{ha} / \mathrm{tahun}$, mutu produk masih rendah serta masih belum optimalnya pengembangan produk hilir kakao. Petani menjual biji kakao dalam bentuk biji kering. Hal ini menjadi suatu tantangan sekaligus peluang bagi para investor untuk mengembangkan usaha dan meraih nilai tambah yang lebih besar dari agribisnis kakao. Rendahnya produktivitas tanaman petani yang berakibat terhadap rendah pendapatan petani. Hal ini disebabkan kurangnya pengetahuan tentang teknik budidaya yang benar. Ditambah lagi, ketidakmampuan petani membiayai lahan pertanian khususnya pembelian sarana seperti pupuk kimia dan pestisida.

Tanaman kakao dibudidayakan secara monokultur. Tidak ada diversifikasi usaha yang dilakukan. Petani hanya mengandalkan pendapatan dari hasil pertanaman kakao. Akibatnya, pendapatan petani berfluktiatif atau tidak merata. Saat musim panen kakao pendapatan meningkat. Sebaliknya saat panen kakao menurun otomatis pendapatan menurun. Padahal, saat itu tanaman kakao memerlukan biaya pemeliharaan yang tinggi misalnya pembelian pupuk dan pestisida.

Permasalahan lain yang dihadapi mitra adalah hasil pangkasan daun, kulit buah dan pangkasan pohon pelindung terbuang sebagai limbah tidak termanfaatkan. Petani umumnya membakar limbah tersebut yang justru bisa berakibat terjadi kerusakan pada tanaman dan lebih berbahaya lagi jika terjadi kebakaran lahan.

Permasalahan ternak, khususnya ternak kambing adalah pakan ternak yang jauh dari lokasi kandang. Pakan ternak diperoleh dari kawasan pinggir hutan. Tidak ada penanaman pakan ternak. Tanaman pakan ternak dibiarkan tumbuh secara liar tanpa ada pemeliharaan. Pakan ternak semakin jauh dari perkampungan atau lokasi kandang ternak kambing. Akibatnya, 1 orang petani hanya mampu memelihara ternak kambing rata-rata 2-3 ekor. 
Usaha ternak yang dilakukan oleh masyarakat umumnya dikelola secara tradisional yang dicirikan oleh pemberian pakan dan kandang yang sederhana. Ciri lain yang dimiliki oleh peternak di Desa Tapango Barat adalah jenis usaha yang dilakukan bukan merupakan usaha pokok. Jenis usaha tidak memperhitungkan sisi ekonomi usaha. Hal tersebut dilatarbelakangi oleh rendahnya kemampuan menajemen yang dikuasai oleh petani peternak. Beberapa keputusan manajemen misalnya keputusan pembelian ternak, keputusan penjualan ternak dan penentuan harga jual ternak kambing sering dilakukan tanpa pertimbangan yang matang. Akibatnya, harga jual yang diterima petani sangat rendah yang berakibat rendahnya pendapatan yang diperoleh petani peternak (Ginting, Simon P., 2014)

Permasalahan yang dialami mitra 2 terutama pada permodalan. Kemampuan menampung hasil produksi petani sangat rendah ketika panen kakao petani bersamaan. Akibatnya, usaha tersebut tidak mampu membeli keseluruhan hasil produksi petani. Permasalahan lain, manajamen keuangan yang belum memadai. Keuangan dikelola secara sederhana. Pembukuan tidak rapih dan tidak ada perencanaan keuangan yang baik. Misalnya saja tidak tersedia nota pembelian.

\section{SOLUSI METODE}

Tahapan pelaksanaan program Program Kemitraan Masyarakat Peningkatan Pendapatan Petani Melalui Integrasi Kakao-Ternak Kambing di Desa Tapango Barat Kecamatan Tapango Kabupaten Polewali Mandar Provinsi Sulawesi Barat. Tahapan pelaksanaan secara garis besar dijelaskan sebagai berikut :

a. Survei pemantapan tentang kesiapan mitra dan lahan yang digunakan. Pada tahapan ini pengusul mulai mendiskusikan dengan mitra tentang kesiapan mitra dan identifikasi lahan yang akan digunakan. Tujuannya memperkuat analisa kelayakan lahan dan kesiapan mitra.

b. Penentuan lokasi lahan pertanaman kakao dan kandang kambing. Pada tahapan ini lokasi penempatan lokasi pertanaman kakao dan posisi kandang sudah ditentukan.

c. Pembuatan Kandang Kambing. Pada tahapan ini dilakukan bersama-sama dengan mitra melakukan pembuatan kandang kambing di sela tanaman kakao. Kandang kambing diletakkan di sela tanaman kakao agar dapat mengatasi permasalahan tentang jauhnya lokasi pengambilan pakan ternak kambing yang selama ini dilakukan. Sekaligus, memudahkan pemberian pupuk pada tanaman kakao hasil kotoran kambing

d. Penambahan/Pengadaan Ternak Kambing. Tahapan ini dilakukan bersama mitra dengan cara menambah jumlah ternak kambing. Tujuannya selain menambah potensi pendapatan dari hasil penjualan kambing juga untuk menambah limbah ternak untuk memenuhi kebutuhan pupuk tanaman kakao. Tahapan ini diharapkan dapat mengatasi sulitnya petani memperoleh pupuk (harga mahal) karena sudah dapat dipenuhi dari pupuk oraganik dari limbah ternak kambing

e. Pembuatan Rumah Kompos. Tahapan ini dilakukan bersama mitra dengan cara membangun rumah kompos. Rumah kompos bertujuan untuk menampung kotoran kambing yang selanjutnya akan dilakukan pembuatan kompos. Kotoran kambing tidak bisa diberikan langsung ke tanaman. Diperlukan penghancuran melalui komponisasi.

f. Pemeliharaan Tanaman Kakao. Pada tahapan ini pemeliharaan kakao dilakukan dengan cara melakukan pemangkasan tanaman kakao maupun pohon pelindung. Selanjutnya Hasil pangkasan daun kakao dan daun pohon pelindung diberikan pada ternak kambing. Komposisi disesuaikan dengan hasil penelitian Zakaria B. (2013) komposisi pakan kambing dapat diberikan yaitu $40 \%$ daun kakao $+60 \%$ daun pelindung. Tahap ini diharapkan dapat mengatasi ketergantungan pakan ternak pada daun gamal. Dan hasil pangkasan daun kakao tidak lagi dibuang di areal pertanaman.

g. Akses perbankan. Pada tahap ini mitra 2 dihubungkan dengan pihak perbankan. Hal ini dilakukan untuk menyelesaikan permasalahan mitra 2 yang kemampuan menampung hasil produksi petani sangat rendah ketika panen kakao petani bersamaan.

h. Pelatihan Pengelolaan Keuangan. Pada tahap ini mitra 2 diberikan pelatihan singkat mengelola keuangan. Pelatihan ini diharapkan dapat menyelesaikan permasalahan manajemen keuangan kelompok usaha tersebut. 


\section{HASIL DAN PEMBAHASAN \\ Pelaksanaan Pendampingan}

Pendampingan kepada mitra dilakukan sejak disetujuinya program Pengabdian Kemitraan Masyarakat (PKM). Pendampingan dilakukan dengan cara melakukan kunjungan setiap minggu. Kunjungan tersebut dilakukan untuk mengetahui lebih detail permasalahan yang dialami oleh mitra dan solusi yang bisa dilakukan.

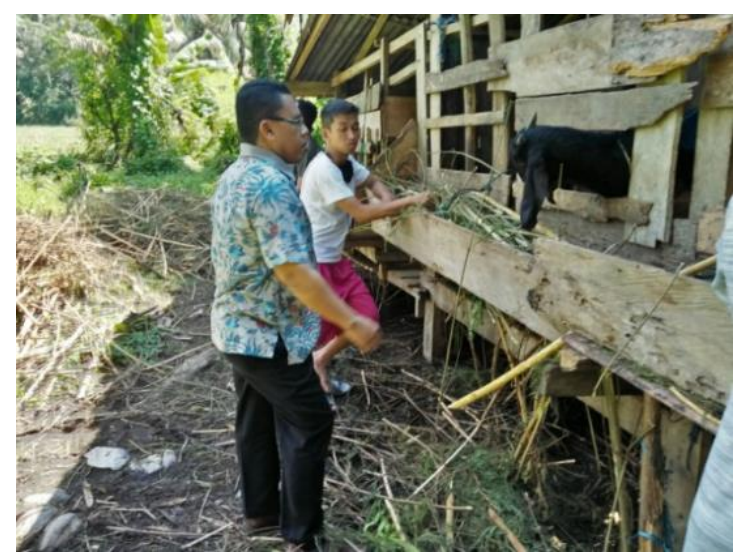

Gambar 1. Kunjungan Awal Pemantapan Pendampingan kepada Mitra

Hasil yang telah dicapai sejak dimulainya kegiatan pengabdian diantaranya berbagai pelatihan kepada mitra telah dilaksanakan antara lain : Pelatihan Peternakan Kambing. Pelatihan dilakukan dengan melibatkan pakar dan praktisi peternakan. Selain dengan mitra juga melibatkan masyarakat petani di sekitar lokasi mitra. Salah satu permasalahan mitra adalah penanganan penyakit ternak kambing yang sering dialami mitra. Solusi yang dilakukan dengan menghadirkan Dokter Hewan. Pelaksanaan pelatihan diikuti praktek penanganan pertama ternak kambing jika mengalami gangguan kesehatan. Selain dokter hewan juga dihadirkan praktisi ternak kambing juga dihadirkan sebagai narasumber yang saat ini, berhasil mengembangbiakan ternak kambing sebanyak 50 ekor dengan memanfaatkan limbah pertanian di sekitarnya.

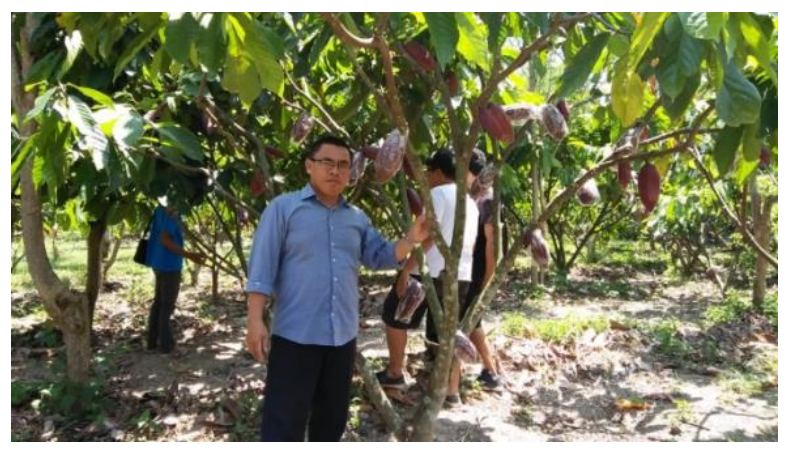

Gambar 2. Kunjungan bersama Mahasiswa di Lokasi Pengabdian

Kunjungan ke lokasi perkebunan kakao mitra dilakukan secara rutin. Penyuluhan perbaikan teknik budidaya dilakukan secara persuasif. Teknik pemeliharaan kakao disampaikan secara langsung ke mitra. Penyampaian dilakukan di sela-sela kunjungan bersama mitra ke lokasi pertanaman. Kunjungan ke pertanaman kakao sering kali melibatkan mahasiswa Pertanian Universitas Al Asyariah Mandar

Berdasarkan hasil kunjungan akhirnya disepakati untuk dilakukannya perbaikan kandang. Perbaikan kandang dilakukan 3 tahun terakhir. Saat ini kondisinya rusak. Hanya bisa menampung 2-3 ekor kambing. Perbaikan dilakukan dengan mengadakan renovasi dan ditempatkan di sekitar pertanaman kakao. Hal ini dilakukan untuk lebih memudahkan dalam pemeliharaan dan pemanfaatan 
kotoran kambing sebagai penyediaan pupuk tanaman kakao lebih dekat. Selain itu, pakan ternak kambing lebih mudah diperoleh di sekitar pertanaman kakao. Perbaikan kandang mitra telah mencapai $100 \%$. Kondisi saat ini telah mampu menampung 6-10 ekor kambing. Lantai kandang dibuat perpanen. Hal ini dilakukan untuk memudahkan penampungan kotoran kambing. Selanjutnya kotoran kambing dikumpulkan dan diletakan di sekitar kandang. Setelah perbaikan, kondisi saat ini terlihat lebih baik. Persyaratan kebersihan kandang telah terpenuhi.

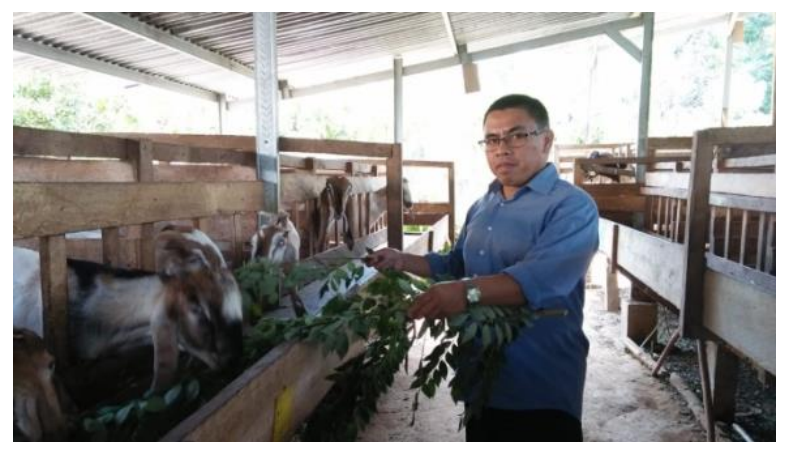

Gambar 3. Kondisi Kandang Kambing setelah renovasi

Capaian lain yang telah dilakukan adalah pelatihan singkat pembuatan kompos berbahan dasar kotoran kambing dan limbah pertanaman kakao. Pelatihan dilakukan dengan melibatkan petani di sekitar lokasi PKM. Pelatihan diikuti 10 orang petani. Selain materi singkat yang dilakukan oleh pengusul, juga dilakukan praktek langsung. Pembuatan bokasi dilakukan karena limbah pertanian berupa kotoran kambing dan limbah kakao dapat terdkomposisi secara cepat.

Selain itu, studi banding ke sentra peternakan juga telah dilakukan. Mitra bersama petani 10 orang petani lainnya diajak berkunjung di Kecamatan Tinambung Kabupaten Polewali Mandar. Kecamatan tersebut merupakan sentra pengembangan ternak kambing di Sulawesi Barat. Kegiatan lain yang telah dilakukan praktek pemupukan dan pemeliharaan pada tanaman kakao dengan menggunakan pupuk kompos yang telah dibuat. Kegiatan ini dilakukan untuk memberi pemahaman kepada mitra dalam budidaya tanaman kakao. Pemahaman

\section{SIMPULAN}

Pola integrasi tanaman kakao dan ternak kambing telah terbentuk pada mitra sehingga telah terjadi sinergisme usaha tani yang saling menguntungkan. Pengetahuan dan Pengetahuan mitra telah mengalami kemajuan khususnya pada teknik budidaya tanaman kakao dan ternak kambing. Terjadi peningktan pendapatan petani dengan mengintegrasikan pertanaman kakao dan ternak kambing

\section{UCAPAN TERIMAKASIH}

Ucapan terima kasih yang paling tulus dan penghargaan kepada Direktorat Riset dan Pengabdian Masyarakat (DRPM) Kementerian Riset, Teknologi dan Perguruan Tinggi (Kemenristekdikti) atas dukungan pada program pengabdian masyarakat ini dan semoga penggunakan fasilitas pengabdian tetap akan diberikan di masa yang akan datang

\section{DAFTAR PUSTAKA}

Asrul, Laode (2014). Agribisnis Kakao. Yayasan FORreST Indonesia dan Fakultas Pertanian Unhas. Makassar. 
Biro Pusat Statistik (2016). Polewali Mandar dalam Angka. BPS. Polewali.

Dwi Priyanto (2008.) Model Usahatani Integrasi Kakao Kambing Dalam Upaya Peningkatan Pendapatan Petani. Balai Penelitian Ternak. Bogor

Ginting, Simon P. (2014). Pedoman Teknis Pemeliharaan Induk dan Anak Kambing Masa Pra-Sapih. Loka Penelitian Kambing Potong, Sumatera Utara.

Hasan Syamsuddin (2012). Hijaun Pakan Ternak daerah Tropis. UI. Press. Bogor.

Nasaruddin (2013). Kakao Budidaya dan Beberapa Aspek Fisiologisnya. Yayasan FORreST Indonesia dan Fakultas Pertanian Unhas. Makassar.

Syakir, Muhammad (2012). Teknologi Budidaya dan Pasca Panen Kakao. Puslitbang Perkebunan. Jakarta

Wahyudi T., dkk. (2014). Panduan Lengkap Kakao, Manajemen Agribisnis dari Hulu hingga Hilir. Penebar Swadaya. Jakarta.

Zakaria, Badron (2013). Integrasi Sistem Produksi Kakao Dan Kambing: Suatu Model Pertanian Terpadu Untuk Meningkatkan Produktivitas, Profitabilitas, Ketahan Usaha Tani Dan Efisiensi Pemanfaatan Sumber Daya. Prosiding Seminar. Unhas. Makassar. 